\title{
Olive oil in food spreads
}

\author{
By Miguel A. Blanco Muñoz
}

Department of Technology Development, PULEVA BIOTECH S.A., Granada, Spain

*Corresponding author: : Dr. Miguel A. Blanco Muñoz. Tel: +34 958240152
Email: mablanco@pulevabiotech.es

\section{CONTENTS}

\section{A SHORT OVERVIEW REFERENCES}

\section{RESUMEN}

\section{El aceite de oliva en alimentos para untar.}

La hidrogenación química de los ácidos grasos insaturados es una reacción que se utiliza con frecuencia en la industria alimentaria. El proceso implica el movimiento de los dobles enlaces en la cadena hidrocarbonada de los ácidos grasos, y la aparición de isómeros posicionales y geométricos (ácidos grasos trans). La ingesta inadecuada de alimentos que pueden contener cantidades significativas de ácidos grasos trans se asocia con el aumento en sangre de colesterol total y LDL, y la disminución de HDL, entre otros efectos. Por lo tanto, el uso de aceite de oliva en la preparación de grasas para untar constituye un importante avance en el desarrollo comercial de nuevos alimentos saludables con una imagen positiva para el consumidor.

PALABRAS-CLAVE: Aceite de oliva; Hidrogenación; Ácidos grasos trans; Ácidos grasos monoinsaturados; Grasa para untar; Dieta Mediterránea.

\section{SUMMARY}

\section{Olive oil in food spreads.}

Chemical hydrogenation of unsaturated fatty acids is a commonly applied reaction to food industries. The process may imply the movement of double bonds in their positions on the fatty acid carbon chain, producing positional and geometrical isomers (trans fatty acids). Through hydrogenation, unsaturated oils are converted to margarines and vegetable shortenings. The presence of trans fatty acids in foods is undesirable, as trans fatty acids raise the plasma levels of total and low-density lipoproteins (LDL), while decrease the plasma level of high-density lipoproteins (HDL), among other effects. The use of olive oil to prepare fat spread opens new insights into the commercial development of healthy novel foods with a positive image in terms of consumer appeal.

KEY-WORDS: Olive oil; Hydrogenation; Trans fatty acids; Monounsaturated fatty acids; Fat spread; Mediterranean diet.

\section{A SHORT OVERVIEW}

Food spreads such as margarine and butter are commonplace in the kitchen. They are used in the home and in the industry for cooking, baking sandwiches and numerous food products. In recent years, attention has been directed to producing healthier food spreads, in the form of reduced fat alternatives to the existing products.

Margarines contain a water phase and an oil phase, which are emulsified. They are generally in the form of a water-in-oil emulsion. The taste of margarines and food spreads is due mostly to water-soluble flavors, oil soluble flavors and salt included in the water phase. Margarine type compounds contain at least $80 \%$ of fat by weight.

In general, fats containing a majority of saturated fatty acids (SFA) are solid at room temperature, and those containing mostly unsaturated fatty acids are usually liquid at room temperature and are called oils. Most naturally occurring dietary unsaturated fatty acids in vegetable oils or polyunsaturated fatty acids (PUFA) of fish oils are of the cis configuration.

Chemical hydrogenation is the process of adding hydrogen atoms to unsaturated sites on the carbon chains of fatty acids, thereby reducing the number of double bonds. The reaction is applied to food industries as partial hydrogenation, by heating vegetable oils (fish oils occasionally) in the presence of metal catalyst and hydrogen. The process of partial hydrogenation accompanied by thermal isomerization, represents incomplete saturation of the double bonds, in which some double bonds remain but may move in their positions on the carbon chain, and produces several geometrical and positional isomers.

Hydrogenation heightens the melting point of fats, which makes it possible to convert fats in liquid form to semi-solids and solids that are useful in many dietary products, increasing shelf life and the flavor stability of unsaturated fatty acids. Cottonseed oil was first hydrogenated in 1911 in the United States to produce vegetable shortening. The partial hydrogenation process became more popular in the 1930's with the development of margarine (IFIC, 1998). Through hydrogenation, oils such as soybean, safflower, and cottonseed oil, which are rich in unsaturated fatty acids, are converted to margarines and vegetable shortenings (Federal register, 1999). 
Thus, trans fatty acids are produced artificially and commercially today. They are present in variable amounts in a wide range of foods, including most foods made with partially hydrogenated oils such as baked goods and fried foods, and some margarine products.

Many years of epidemiological research have shown that populations consuming diets high in SFA have relatively high levels of serum cholesterol and carry a high prevalence of coronary heart disease (as shown earlier by Keys, 1980; Kromhout and Lezenne, 1984; Caggiula and Mustad, 1997; and reviewed in issue 3). Based on the evidence of these studies, it is generally accepted that high levels of serum cholesterol, particularly low-density lipoprotein (LDL) cholesterol, promote the development of atherosclerosis and predispose to coronary heart disease. The concept has become widely accepted that lowering LDL cholesterol by virtually any safe means will reduce the risk of coronary heart disease (Gould et al., 1998).

One study in 1990 demonstrated that trans fatty acids raised total and LDL cholesterol while lowering high-density lipoprotein (HDL) cholesterol (Mensink and Katan, 1990). As a result, the net effect of trans fatty acids on the ratio of LDL to HDL cholesterol was approximately double that of the SFA. These adverse effects of trans fatty acids have been confirmed by subsequent metabolic studies.

Strong epidemiological evidence relating dietary factors to the risk of coronary heart disease has been provided by large prospective studies. Those studies assessed the intake of trans fatty acids using detailed food-frequency questionnaires whose results were validated by comparison with the composition of adipose tissue or food diaries. Each of these studies reported high relative risk of coronary heart disease associated with the intake of trans fatty acids (Willet et al., 1993; Ascherio et al., 1996; Pietinen et al., 1997; Oomen et al., 2001).

Butter has been probed to produce a small, but significant rise in the total serum cholesterol and LDL cholesterol, relative to other fats. Enrichment of butter with either olive oil $(50 / 50)$ or sunflower oil $(50 / 50)$ failed to reduce serum lipid levels below habitual diet values. Hard margarine, containing 29\% trans fatty acids, caused a decrease in apolipoprotein A-I and B levels, but did not change total serum cholesterol or LDL cholesterol levels, relative to habitual diet values. The data indicated that trans fatty acids are not metabolically equivalent to the natural cis isomers and that they can affect the serum lipid profile adversely (Wood et al., 1993). Therefore, an olive based fat spread could help, not only to reduce LDL cholesterol, but also not to raise the ratio of LDL/HDL cholesterol as the trans fatty acids do.

The first commercial development of a spread made from a combination of butterfat and vegetable oil was a product named Bregott, in Sweden forty years ago. It contains around $65 \%$ milk fat and $15 \%$ soybean oil. The manufacturing technique is the same as butter. The cream is pasteurized followed by cooling, and oil is mixed in the churn or the oil is continuously injected before churning in a continuous butter machine. One of the first companies in Europe with a fat spread containing olive oil was Benecol ${ }^{\circledR}$.

In terms of product competition, the yellow fat market is dominated overall by soft margarines, followed by butters, with dairy, polyunsaturated spreads and low fat spreads following in approximate order of market share. The source oils for these products are mainly dairy and vegetable. A more recent introduction has been the application of olive oil as a major source fat in this respect, but still with a much smaller market share than other oils.

Olive oil and products based on it, which are high in monounsaturated fatty acids (MUFA), are promoted as part of the Mediterranean diet which is currently viewed as making a favorable dietary contribution. Thus, in this respect, olive oil in the diet can be recommended, and has a positive image in terms of consumer appeal. There is also a possible negative image for a wider consumer market in the northern countries because its use as medicinal form for many decades, and its consumption is very low compared with southern European countries.

Traditionally in the Mediterranean diet, the oil is consumed in the pure form, either as a basting or frying aid. Although the most common use of olive oil is in as such, in the liquid form, it is acknowledged that a more pleasant way to consume the oil is in the form of a spread. There are also some indications that presentation of a healthy image for a food product may not per se ensure consumer acceptance. Consumer attitudes to this new source oil used in spread form and its associated sensory appeal and image has been explored and the selection and acceptance of a new food product depends on many factors which include the foods sensory properties and the information imparted to the consumer (Bower and Saadat, 1998).

\section{REFERENCES}

Ascherio, A., Rimm, E.B., Giovannucci, E.L., Spiegelman, D., Stampfer, M., Willett, W.C. (1996). Dietary fat and risk of coronary heart disease in men: cohort follows up study in the United States. Br. Med. J., 313, 84--90.

Bower, J.A., Saadat, M.A. (1998). Consumer preference for retail fat spreads: an Olive oil based product compared with market dominant brands. Food Quality Preference, 9, 367-376.

Caggiula, A.W., Mustad, V.A. (1997). Effects of dietary fat and fatty acids on coronary artery disease risk and total and lipoprotein cholesterol concentrations: epidemiologic studies. Am. J. Clin. Nutr., 65, 1597S--1610S 
Federal register (1999). http://www.fda.gov/OHRMS/ DOCKETS/98fr/111799c.pdf

Gould, A.L., Rossouw, J.E., Santanello, N.C., Heyse, F.J., Furberg, C.D. (1998). Cholesterol reduction yields clinical benefit: impact of statin trials. Circulation, 97, 946--952.

IFIC review (1998). Sorting out of the facts about fat (http://ificinfo.health.org/review/ir-fat.htm).

Keys, A. (1980). Coronary heart disease, serum cholesterol, and the diet. Acta Med. Scand., 207, 153--160.

Kromhout, D., de Lezenne, C.C. (1984). Diet, prevalence and 10-year mortality from coronary heart disease in 871 middle-aged men. Zutphen Study. Am. J. Epidemiol., 119, 733--741.

Mensink, R.P., Katan, M.B. (1990). Effect of dietary trans fatty acids on high-density and low-density lipoprotein cholesterol levels in healthy subjects. N. Engl. J. Med., 323, 439--445.

Oomen, C.M., Ocke, M.C., Feskens, E.J.M., van Erp-Baart, M.A., Kok, F.J., Kromhout, D. (2001).
Association between trans fatty acid intake and 10 -year risk of coronary heart disease in the Zutphen Elderly Study: a prospective population-based study. Lancet, 357, 746--750.

Pietinen, P., Ascherio, A., Korhonen, P. (1997). Intake of fatty acids and risk of coronary heart disease in cohort of Finnish men: the Alpha-Tocopherol, Beta-Carotene Cancer Prevention Study. Am. J. Epidemiol., 145, 876--887.

Willet, W.C., Stampfer, M.J., Manson, J.E., Colditz, G.A., Speizer, F.E., Rosner, B.A., Sampson, H.A., Henns, C.H. (1993). Intake of trans fatty acids and risk of coronary heart disease among women. Lancet, 341, $581-585$.

Wood, R., Kubena, K., O’Brien, B., Tseng, S., Martin, G. (1993). Effect of butter, mono and polyunsaturated fatty acid-enriched butter, trans fatty acid margarine, and zero trans fatty acid margarine on serum lipids and lipoproteins of healthy men. J. Lipid Res., 34, $1-11$. 